medRxiv preprint doi: https://doi.org/10.1101/2021.11.22.21266701; this version posted November 24, 2021. The copyright holder for this

\title{
Predictors of Treatment Response, Remission, Relapse and Rehospitalization in First-Episode Psychosis Patients in Medellin, Colombia
}

Jenny Garcia, MD, PhD ${ }^{\mathrm{a}}$; Lina M. Agudelo, $\mathrm{MD}^{\mathrm{b}}$; Maria A. Canas, $\mathrm{MD}^{\mathrm{c}}$; Natalia Castro-Campos, MD, MS ${ }^{\mathrm{d}}$; Oscar J. Ribero, $\mathrm{MD}^{\mathrm{b}}$; Juan A. Gallego, MD, MS ${ }^{\mathrm{e}, \mathrm{f}, \mathrm{g}^{*}}$

${ }^{a}$ Universidad de Antioquia, Medellin, Colombia

${ }^{\mathrm{b}}$ Hospital Mental de Antioquia, Medellin, Colombia

${ }^{\mathrm{c}}$ Universidad CES, Medellin, Colombia

${ }^{\mathrm{d}}$ Universidad del Rosario, Bogota, Colombia

${ }^{\mathrm{e}}$ Division of Psychiatry Research, The Zucker Hillside Hospital, Glen Oaks, NY

${ }^{\mathrm{f}}$ Institute for Behavioral Science, The Feinstein Institute for Medical Research, Manhasset, NY

${ }^{\mathrm{g}}$ Department of Psychiatry, Donald and Barbara Zucker School of Medicine at Hofstra/Northwell, Hempstead, NY

Address correspondence and reprint request to:

*Juan A. Gallego MD, MS.

75-59 $263^{\text {rd }}$ street

Glen Oaks, NY 11004

Tel: $718-470-4588$

Email address: jgallego@northwell.edu 
medRxiv preprint doi: https://doi.org/10.1101/2021.11.22.21266701; this version posted November 24, 2021. The copyright holder for this preprint (which was not certified by peer review) is the author/funder, who has granted medRxiv a license to display the preprint in perpetuity. All rights reserved. No reuse allowed without permission.

\begin{abstract}
$\underline{\text { Abstract }}$
Background: Most studies with first episode psychosis patients have been conducted in high-income countries. On the other hand, very few first episode studies have been conducted in Latin-America. Therefore, the goal of our study is to determine predictors of treatment response, remission, relapse and rehospitalization in a first episode psychosis population from Medellin, Colombia.
\end{abstract}

Methods: Data was obtained from electronic health records from first episode patients with a diagnosis of schizophrenia-spectrum disorder diagnoses who were evaluated between January 2014 and December 2016 at two psychiatric institutions in Medellin, Colombia. Survival and Cox proportional hazard models were used for the analysis.

Results: Duration of untreated psychosis and hospitalization at the time of presentation was associated with both response and remission. Response was also predicted by less first-order symptoms and more years of education. Remission was predicted by older age of onset. Relapse and rehospitalization were predicted by use of substances and poor adherence to pharmacologic treatment. Less years of education and hospitalization at the time of presentation were also associated with rehospitalization.

Conclusion: Predictors of treatment response, remission, relapse and rehospitalization in first-episode patients are similar in Colombia compared to other high-income regions such as the United States and Europe.

Keywords: schizophrenia, first episode, Colombia, Medellin, predictors, treatment response 
medRxiv preprint doi: https://doi.org/10.1101/2021.11.22.21266701; this version posted November 24, 2021. The copyright holder for this

\section{Introduction}

Schizophrenia is an illness with a prevalence rate of 0.33 to $0.75 \%$ of the population (Saha et al., 2005; Moreno-Küstner et al., 2018). Despite the relatively low prevalence rates, it is considered the 15th cause of years lived with disability in the world (GBD., 2016) and is associated with premature mortality (Olfson et al., 2015) and higher financial burden (Desai et al., 2013). For the past several years, the field has been conducting studies with patients who present with a first episode (FE) of the illness to study neuropathophysiological abnormalities, to determine the efficacy and safety of treatments in the absence of confounding factors such as cumulative effect of antipsychotic treatment or a long duration of illness and to investigate the impact of early interventions in the long-term outcome of schizophrenia.

Most studies with first episode schizophrenia patients have been conducted in the US (Schooler et al., 2005; McEvoy et al., 2007; Robinson et al., 2015; Kane et al., 2015), Europe (Kahn et al., 2008; CrespoFacorro et al., 2013) and South Africa (Emsley et al., 1999). Accordingly, the evidence regarding predictors of either treatment response, remission, relapse or rehospitalization are derived from those studies. For example, a shorter duration of untreated psychosis (DUP) has been consistently found as a predictor of good response to treatment (Perkins et al., 2004) and/or remission of symptoms (Lieberman et al., 1996; Robinson et al., 2004; Emsley et al., 2007). Similarly, good premorbid functioning has been associated with good clinical response (Perkins et al., 2004; Rabinowitz et al., 2006; Crespo-Facorro et al., 2007). On the contrary, an early age of onset, poor adherence to treatment and comorbid substance use disorders have been associated with worse clinical outcomes, including relapse and rehospitalization (Robinson et al., 1999; Crespo-Facorro et al., 2007).

Unfortunately, even though Latin America comprises 20 countries and more than 600 million people, very few longitudinal FE studies have been conducted and only a handful of specialized FE teams have been established, mostly in Brazil, Chile and Mexico (Aceituno et al., 2020). Based on our literature 
medRxiv preprint doi: https://doi.org/10.1101/2021.11.22.21266701; this version posted November 24, 2021. The copyright holder for this

review, we just found three clinical trials (Apiquian et al., 2003; Valencia et al., 2012; Valencia et al., 2017), few reports describing a naturalistic follow-up of clinical samples (Attux et al., 2007; Trzesniak et al., 2012; Gonzalez-Valderrama., 2017; Cano et al., 2021), a number of short, acute treatment studies used to examine neuroimaging or genetic markers (De La Fuente-Sandoval et al., 2013; Santoro et al, 2018) or chart reviews with a longitudinal component (Gomez-de-Regil et al., 2010; Markkula et al., 2011; Mena et al., 2018).

Given the small number of studies, only few demographic and illness predictors of clinical outcomes have been reported. Gomez-de-Regil and colleagues (2010) found that residual symptoms of psychosis were associated with a lower level of education and an insidious onset of symptoms. Mena and colleagues (2018) found that males with a younger onset of psychosis were over-represented in a group of first episode schizophrenia (FES) patients who received clozapine. Cano and colleagues (2021) followed 50 FES patients naturalistically for up to 5 years and found that poor functioning was predicted by a higher number of relapses, hospitalizations, and changes in the antipsychotic regimen. Lastly, GonzalezValderrama and colleagues (2017) found that a shorter DUP was associated with a more robust improvement in negative symptoms.

Therefore, to expand on the current body of work, we present longitudinal data obtained from electronic health records (EHR) from a large FEP sample from Medellin, Colombia, to determine sociodemographic, illness and treatment predictive factors associated with treatment response, remission of symptoms, relapse and rehospitalization. Given that factors such as trauma, violence, and poverty have been associated with schizophrenia, and that these factors are commonly present in Latin-American countries, we hypothesize that other predictive factors may be more prominent in Latin American FE samples compared to other higher income countries. 
medRxiv preprint doi: https://doi.org/10.1101/2021.11.22.21266701; this version posted November 24, 2021. The copyright holder for this

\section{Methods}

\section{$\underline{2.1 \text { Data extraction }}$}

Data was extracted EHR from two institutions in Medellin, Colombia: 1) the Hospital Mental de Antioquia, and 2) Clinica Samein. Both institutions serve patients from all socioeconomic classes and have a psychiatric emergency room, inpatient and outpatient services. Inclusion criteria: 1) Ages 65 or younger; 2) presented for psychiatric treatment for the first time between January $1^{\text {st }} 2014$ and December $31^{\text {st }} 2016$; 3) ICD-10 diagnosis of schizophrenia (F20), schizoaffective disorder (F25) or brief psychotic disorder (F23). The following exclusion criteria were applied: 1) Dementia; 2) Moderate and severe intellectual disability; 3) ICD-10 diagnosis of substance-induced psychosis (F19); 4) psychosis due to a general medical condition.

For each patient, the following information was extracted directly from the EHR based on the initial and subsequent psychiatric evaluations and for a period of up to 12 months in each individual: sociodemographic information, psychiatric diagnosis, psychiatric symptoms, treatment received and presence or absence of hospitalizations. Information was extracted, reviewed and entered in a database by J.G and L.A. Of note, there was no direct contact with patients. All information was obtained from the EHR. This protocol was reviewed and approved by the ethics committee at both institutions.

\section{$\underline{2.2 \text { Outcome Definition }}$}

Response, remission, relapse and rehospitalization were the outcomes of interest in the study. To determine the outcomes, all psychiatric notes for each patient for a period of up to 12 months were reviewed by J.G, O.R. and L.A. Based on this information, the following definition was coded for each outcome: 1) response was coded when the treating psychiatrist reported that patient's symptoms were improving; 2) remission was coded when the treating psychiatrist reported that positive symptoms of psychosis were no longer present 3) relapse was defined as a return of psychotic symptoms in those patients who had initially remitted according to the notes from the treating psychiatrist 4) 
medRxiv preprint doi: https://doi.org/10.1101/2021.11.22.21266701; this version posted November 24, 2021. The copyright holder for this

rehospitalization was coded when patients had a second hospitalization after an initial hospitalization or a first hospitalization if they had not been initially hospitalized.

\section{$\underline{2.3 \text { Statistical Analysis }}$}

Patients were grouped based on diagnostic categories (schizophrenia, schizoaffective disorder and brief psychotic disorder). Continuous variables were summarized using mean and SD when normally distributed or median and interquartile range if not normally distributed. An Anova test was used to compare continuous variables across the three groups. Categorical variables were compared using contingency tables and chi-square tests. Lastly, a multivariate Cox hazard regression model was calculated for each of the four outcomes. All relevant clinical variables with potential effects on the outcome were entered in the model.

\section{Results}

\subsection{Subjects included}

One-thousand-five-hundred and ninety-three patients (1593) patients who were evaluated for the first time between January $1^{\text {st }} 2014$ and December $31^{\text {st }} 2016$ were first identified. Of those, 805 (62.7\%) were excluded for having a prior psychiatric visit at other institutions, 363 (28.3\%) for not having the selected ICD-10 codes, 76 (5.9\%) for having intellectual disability, 18 for having dementia (1.4\%), 16 (1.2\%) for having delusional disorder, and $5(0.4 \%)$ for having schizotypal personality disorder. Three hundred and ten patients were finally included in the analysis (Figure 1).

\section{Fig 1. Approx. here}

\subsection{Subject Characteristics}

In the overall group, patients were mostly male $73.5 \%$, single $(80.1 \%)$ and had a median age of 25 years (IQR=19-38). They had been in school for a median of 11 years (IQR=7-11) and had a median duration of psychotic symptoms of 120 days (IQR=25.5-720). Forty one percent had low socio-economic status, $90.3 \%$ were living with family and $58.6 \%$ were hospitalized at the time of first presentation. Of the 310 
medRxiv preprint doi: https://doi.org/10.1101/2021.11.22.21266701; this version posted November 24, 2021. The copyright holder for this

patients included, $260(83.9 \%)$ had schizophrenia, 10 (3.2\%) had schizoaffective disorder and 40 (12.9\%) had a brief psychotic disorder. The three groups were largely similar except for patients in the brief psychotic disorder group who had, compared to patients in the SZ and SAD groups, significantly shorter duration of psychotic symptoms ( $\mathrm{p}=0.0001)$, lower frequency of first-order symptoms $(\mathrm{p}=0.01)$, and less blunted/flat affect $(<0.001)$, alogia $(\mathrm{p}=0.037)$ and abulia $(\mathrm{p}=0.13)($ Table 1$)$.

\section{Table 1. Approx. here}

\section{$\underline{3.3 \text { Treatment characteristics }}$}

The most commonly used antipsychotic medication was olanzapine (60.2\%), followed by risperidone (46.3\%) and haloperidol (13.6\%). Interestingly, a good number of patients were treated with risperidone long-acting injectable (LAI) (11.4\%), pipotiazine palmitate LAI $(7,1 \%)$ and clozapine $(6.8 \%)$. In addition, about a quarter of patients were treated with two or more antipsychotic medications (23.3\%), antidepressants (23.9\%) or mood stabilizers (25.6\%). 37.2\% of patients were treated with benzodiazepines (Table 2).

\section{Table 2. Approx. here}

\section{$\underline{3.4 \text { Predictors }}$}

As described previously and observed in table 1, patients with brief psychotic disorder differed from the schizophrenia and schizoaffective disorder groups in several baseline variables. Moreover, out of the 40 patients with a brief psychotic disorder diagnosis, 23 dropped out of treatment either right after the baseline visit or right after hospitalization; therefore, only 17 of those patients provided follow-up data. Furthermore, all 17 patients achieved full remission and were not re-hospitalized. Therefore, we decided to exclude this group from the regression analysis and restrict our analysis to patients with schizophrenia and schizoaffective disorder. Lastly, we further excluded 53 patients from the regression analysis, given that they only provided data from the baseline visit. 
medRxiv preprint doi: https://doi.org/10.1101/2021.11.22.21266701; this version posted November 24, 2021. The copyright holder for this

3.4.1 Treatment response: two hundred and one out of 232 patients responded to treatment (86.6\%).

Higher response rates were associated with duration of psychosis $\leq 6$ months (adjHR=0.58, 95\%CI $=0.40$ -

0.78, $\mathrm{p}<0.0001)$, lower frequency of first-order symptoms $(\operatorname{adjHR}=0.52,95 \% \mathrm{CI}: 0.34-0.81, \mathrm{p}=0.004$,

hospitalization at the time of presentation $(\operatorname{adjHR}=3.69,95 \% \mathrm{CI}: 2.29-5.91, \mathrm{p}<0.0001)$ and $\geq$ eleven years of education $(\operatorname{adjHR}=1.51,1.01-2.24, \mathrm{p}=0.04)($ Supplemental table 1$)$

3.4.2 Remission: One hundred thirty five of 260 (58.2\%) patients achieved remission. Median time to remission of symptoms was 32 days (IQR: 17-118). As observed with treatment response, a duration of psychosis $\leq 6$ months was associated with increased rates of remission $(\operatorname{adjHR}=0.52,95 \%$ CI: $0.34-$ $0.79, \mathrm{p}=0.002)$ along with an older age of onset $(\operatorname{adjHR}=0.47,95 \% \mathrm{CI}: 0.28-0.82, \mathrm{p}=0.007)$ and hospitalization at the time of presentation (adjHR: 2.32, 95\% CI:1.39-3.88, p=0.001) (Supplemental table 2)

3.4.3 Relapse: Out of the 201 patients who responded to treatment, 88 (43.8\%) relapsed. Median time to relapse was 218 days (IQR: 90-369) with a median number of relapses of 1 (IQR: 1-2, range: 1-6). As expected, relapse was predicted by use of substances (adjHR: 2.61, 95\% CI:1.32-5.15, p=0.0006) and poor adherence to pharmacologic treatment (adjHR 0.38, 95\% CI: 0.22-0.65, p<0.0001) (Supplemental table 3).

3.4.4 Rehospitalization: 72 patients were hospitalized during follow-up (31.0\%). Median time to hospitalization was 266 days (IQR: 90-610) and median number of hospitalizations was 1 (IQR:1-2, range 1-7). Increased rates were associated with use of substances (adjHR:3.39, 95\% CI:1.38-8.32, p=0.008), poor adherence to pharmacologic treatment (adjHR:0.35, 95\% CI:0.18-0.68, $\mathrm{p}=0.002$ ), less than 11 years of education (adjHR:0.46, 95\% CI:0.26-0.83, p=0.009) and hospitalization at the time of presentation $(\operatorname{adjHR}: 2.52,95 \%$ CI:1.11-5.72, p=0.03) (Supplemental table 4). 
medRxiv preprint doi: https://doi.org/10.1101/2021.11.22.21266701; this version posted November 24, 2021. The copyright holder for this

\section{Discussion}

This study is one of the few studies conducted in Latin America reporting on longitudinal outcomes of first episode schizophrenia patients. We found that a better response to treatment was associated with shorter DUP, more years of education, less first-order symptoms and being hospitalized at the time of presentation. A shorter DUP and being hospitalized at the time of presentation was also associated with remission of symptoms along with an older age of onset. Predictably, relapse and rehospitalization were both predicted by use of substances and poor adherence to treatment but having less years of education and being hospitalized at the time of presentation also predicted rehospitalization.

There are few points of comparison given the limited number of FEP studies from Latin America, but our finding that remission of symptoms was associated with an older age of onset was similar to the finding by Mena and colleagues (2018) who found that early treatment resistance was associated with younger age of onset. Similarly, our finding that a shorter DUP was associated with better overall response and remission of symptoms is in agreement with the findings by Gonzalez-Valderrama (2017) who found that a shorter DUP was associated with improvement in negative symptoms.

Importantly, the demographic characteristics of the patients in our study are very similar to the demographic characteristics of large RCTs with FEP studies conducted in high income countries. For example, patients included in our study had a median age of $25 \mathrm{y} / \mathrm{o}$, were $73 \%$ male, and $90 \%$ were living with family and those numbers were comparable to patients in the RAISE study (Kane et al., 2015) (mean age $=23 \mathrm{y} / \mathrm{o}, 66 \%$ male, and $71 \%$ living with family), and the EUFEST study (Kahn et al., 2008) (mean age $=25 \mathrm{y} / \mathrm{o}, 60 \%$ male, and $86 \%$ living with family or somebody else). Similarly, when comparing treatment practices between our patients in our study and those included in the RAISE study at the time of enrollment (Robinson et al., 2015), we found that the two most common used antipsychotics in both studies were risperidone and olanzapine, however, the use of olanzapine in our study is much higher compared to the RAISE study (60.2\% vs. $17 \%)$, even though olanzapine is not a first line treatment for FEP patients (Kreyenbuhl et al., 2010). Interestingly, the use of clozapine (6.8\% vs. $0.7 \%$ ), mood 
medRxiv preprint doi: https://doi.org/10.1101/2021.11.22.21266701; this version posted November 24, 2021. The copyright holder for this preprint (which was not certified by peer review) is the author/funder, who has granted medRxiv a license to display the preprint in perpetuity. All rights reserved. No reuse allowed without permission.

stabilizers (25.6\% vs. $9.2 \%)$ and anti-anxiety medications (37.2\% vs. $10.4 \%)$ was higher in our study compared to RAISE, whereas patients enrolled in RAISE had higher use of antidepressants compared to our study (31.9\% vs. $23.9 \%)$.

Our findings mirror the findings of high-income countries in regard to predictors of clinical outcomes. We found that a shorter DUP was associated with better response and/or remission and this has been reported by several other studies (Lieberman et al., 1996; Robinson et al., 2004; Perkins et al., 2004; Emsley et al., 2007). Similarly, our finding that a later age of onset was associated with remission was also observed by other investigators (Malla et al., 2006; Crespo-Facorro et al., 2007). Moreover, we replicated the finding that co-morbid substance use and non-adherence to treatment are strongly associated with relapse and rehospitalization (Robinson et al., 1999; Alvarez-Jimenez et al., 2012; Caseiro et al., 2012; Addington et al., 2013). Lastly, our finding that hospitalization at presentation was predictive of rehospitalization was also reported by Addington and colleagues (2013).

Our study has several limitations. Firstly, data was collected as part of routine psychiatric care and therefore it is likely that data was not as carefully collected and entered as if it was a research study. On the other hand, all data was obtained from the EHR, which allowed us to historically review every single visit in every patient. An important limitation is that the definition of our outcomes was based on the text entered by the psychiatrist in the EHR. Even though phrases such as "patient is getting better, patient is improving" are often vague in clinical practice, they do reflect the clinician's perception of the patient's clinical condition, which in turn leads to treatment decisions. Strengths of our study include the inclusion of a large first episode schizophrenia sample collected in an urban environment from a lower-middle income (LMIC) country. Furthermore, we had the opportunity to review and obtain longitudinal data from EHR from a large group of patients which allowed us to arrive to clinically relevant outcomes in each individual. Therefore, with this study we demonstrate predictors or clinically relevant outcomes in "real world" conditions in Colombia, South America, in contrast to data obtained from specialized research clinics in academic centers in the US or Europe. 
medRxiv preprint doi: https://doi.org/10.1101/2021.11.22.21266701; this version posted November 24, 2021. The copyright holder for this

Given that we demonstrated that first episode schizophrenia patients in Medellin, Colombia, have similar demographical and clinical characteristics compared to first episode schizophrenia patients in the US and Europe, research studies could be conducted in this region to either test the feasibility and implementation of interventions developed in high income countries, such as the Navigate intervention, developed as part of the Recovery After Initial Schizophrenia Episode RAISE study (Kane et al., 2015). The successful implementation of these type of interventions in LIMC like Colombia, delivered by a well-trained and highly specialized teams, as is the case in the OnTrackNY program (Nossel et al., 2018), would likely lead to better psychosocial functioning, reduced psychopathology and better quality of life (Nossel et al., 2018).

\section{Acknowledgements}

The authors would like to thank Taylor Marzouk for proofreading the manuscript.

\section{Funding}

This research did not receive any specific grant from funding agencies in the public, commercial, or notfor-profit sectors.

\section{Author contributors}

Garcia, J: Conceptualization, Methodology, Writing original draft, Formal analysis. Agudelo, LM:

Conceptualization, Investigation, Writing- Reviewing and Editing. Canas, MA: Writing- Reviewing and Editing, Visualization. Castro-Campos N: Writing- Reviewing and Editing, Visualization. Ribero, O: Investigation, Writing- Reviewing and Editing. Gallego, J: Conceptualization, Methodology WritingReviewing and Editing, Supervision, Formal analysis.

\section{Declarations of interest: none}


medRxiv preprint doi: https://doi.org/10.1101/2021.11.22.21266701; this version posted November 24, 2021. The copyright holder for this

\section{References}

Aceituno, D., Mena, C., Vera, N., Gonzalez-Valderrama, A., Gadelha, A., Diniz, E., Crossley, N.,

Pennington, M., \& Prina, M., 2021. Implementation of early psychosis services in Latin America: A scoping review. Early intervention in psychiatry, 15(5), 1104-1114. https://doi.org/10.1111/eip.13060

Addington, D. E., McKenzie, E., Norman, R., Wang, J., \& Bond, G. R., 2013. Essential evidence-based components of first-episode psychosis services. Psychiatric services (Washington, D.C.), 64(5), 452-457. https://doi.org/10.1176/appi.ps.201200156

Alvarado, R., Valencia, E., Madariaga, C., Alieste, F., Minoletti, A., \& Sepúlveda, R., 2015. Revista de la Facultad de Ciencias Medicas (Cordoba, Argentina), 72(4), 220-226.

Alvarez-Jimenez, M., Priede, A., Hetrick, S. E., Bendall, S., Killackey, E., Parker, A. G., McGorry, P. D., \& Gleeson, J. F., 2012. Risk factors for relapse following treatment for first episode psychosis: a systematic review and meta-analysis of longitudinal studies. Schizophrenia research, 139(1-3), 116-128. https://doi.org/10.1016/j.schres.2012.05.007

Apiquian, R., Fresán, A., Herrera, K., Ulloa, R. E., Lóyzaga, C., de la Fuente-Sandoval, C., Gutiérrez, D., \& Nicolini, H., 2003. Minimum effective doses of haloperidol for the treatment of first psychotic episode: a comparative study with risperidone and olanzapine. The international journal of neuropsychopharmacology, 6(4), 403-408. https://doi.org/10.1017/S1461145703003742

Attux, C., Quintana, M. I., \& Chaves, A. C., 2007. Weight gain, dyslipidemia and altered parameters for metabolic syndrome on first episode psychotic patients after six-month follow-up. Revista brasileira de psiquiatria (Sao Paulo, Brazil : 1999), 29(4), 346-349. https://doi.org/10.1590/s1516-44462006005000061

Caseiro, O., Pérez-Iglesias, R., Mata, I., Martínez-Garcia, O., Pelayo-Terán, J. M., Tabares-Seisdedos, R., Ortiz-García de la Foz, V., Vázquez-Barquero, J. L., \& Crespo-Facorro, B., 2012. Predicting relapse after a first episode of non-affective psychosis: a three-year follow-up study. Journal of psychiatric research, 46(8), 1099-1105. https://doi.org/10.1016/j.jpsychires.2012.05.001 
medRxiv preprint doi: https://doi.org/10.1101/2021.11.22.21266701; this version posted November 24, 2021. The copyright holder for this

Cano, J. F., Ortegón-Valencia, J., Pedraza-Perez, C., Córdoba-Rojas, R., Olarte-Armenta, A., VallejoSilva, A., \& González-Díaz, J., 2021. Functionality During the First Five Years After the Diagnosis of Schizophrenia. A Cohort Study in a Colombian Population. Revista Colombiana de psiquiatria (English ed.), S0034-7450(20)30117-7. Advance online publication. https://doi.org/10.1016/j.rcp.2020.11.005

Chaves, AC., 2007. Primeiro episódio psicótico: uma janela de oportunidade para tratamento? First episode psychosis: a window of treatment opportunity; Revisões da Literatura. Arch. Clin. Psychiatry (São Paulo) 34 (suppl 2).https://doi.org/10.1590/S0101-60832007000800005

Crespo-Facorro, B., Pelayo-Terán, J. M., Pérez-Iglesias, R., Ramírez-Bonilla, M., Martínez-García, O., Pardo-García, G., \& Vázquez-Barquero, J. L., 2007. Predictors of acute treatment response in patients with a first episode of non-affective psychosis: sociodemographics, premorbid and clinical variables. Journal of psychiatric research, 41(8), 659-666. https://doi.org/10.1016/j.jpsychires.2006.05.002

Crespo-Facorro, B., Ortiz-García de la Foz, V., Mata, I., Ayesa-Arriola, R., Suarez-Pinilla, P., Valdizan, E. M., Vázquez-Barquero, J. L., \& Pérez-Iglesias, R., 2013. Aripiprazole, Ziprasidone and Quetiapine in the treatment of first-episode nonaffective psychosis: a 12-week randomized, flexible-dose, open-label trial. Schizophrenia research, 147(2-3), 375-382. https://doi.org/10.1016/j.schres.2013.04.014

De la Fuente-Sandoval, C., León-Ortiz, P., Azcárraga, M., Stephano, S., Favila, R., Díaz-Galvis, L., Alvarado-Alanis, P., Ramírez-Bermúdez, J., \& Graff-Guerrero, A., 2013. Glutamate levels in the associative striatum before and after 4 weeks of antipsychotic treatment in first-episode psychosis: a longitudinal proton magnetic resonance spectroscopy study. JAMA psychiatry, 70(10), 1057-1066. https://doi.org/10.1001/jamapsychiatry.2013.289

Desai, PR, Lawson, KA, Barner, JC, Rascati, KL., 2013. Estimating the direct and indirect costs for community-dwelling patients with schizophrenia. Journal of Pharmaceutical Health Services Research, 2013 Jul;4(4):187-194. doi/10.1111/jphs.12027/epdf 
medRxiv preprint doi: https://doi.org/10.1101/2021.11.22.21266701; this version posted November 24, 2021. The copyright holder for this preprint (which was not certified by peer review) is the author/funder, who has granted medRxiv a license to display the preprint in perpetuity. All rights reserved. No reuse allowed without permission.

Emsley R. A., 1999. Risperidone in the treatment of first-episode psychotic patients: a double-blind multicenter study. Risperidone Working Group. Schizophrenia bulletin, 25(4), 721-729. https://doi-org.eresources.mssm.edu/10.1093/oxfordjournals.schbul.a033413

Emsley, R., Rabinowitz, J., Medori, R., \& Early Psychosis Global Working Group., 2007. Remission in early psychosis: Rates, predictors, and clinical and functional outcome correlates. Schizophrenia research, 89(1-3), 129-139. https://doi.org/10.1016/j.schres.2006.09.013

Gaebel, W., Peuskens, J., Lindefors, N., Riecher-Rössler, A., Grobbee, D. E., \& EUFEST study group., 2008. Effectiveness of antipsychotic drugs in first-episode schizophrenia and schizophreniform disorder: an open randomised clinical trial. Lancet (London, England), 371(9618), 1085-1097. https://doi-org.eresources.mssm.edu/10.1016/S0140-6736(08)60486-9

GBD 2016 Disease and Injury Incidence and Prevalence Collaborators. Global, regional, and national incidence, prevalence, and years lived with disability for 328 diseases and injuries for 195 countries, 1990-2016: a systematic analysis for the Global Burden of Disease Study 2016. Lancet. 2017 Sep 16;390(10100):1211-1259. doi: 10.1016/S0140-6736(17)32154-2. Erratum in: Lancet. 2017 Oct 28;390(10106):e38. PMID: 28919117; PMCID: PMC5605509.

González-Valderrama, A., Castañeda, C. P., Mena, C., Undurraga, J., Mondaca, P., Yañez, M., Bedregal, P., \& Nachar, R., 2017. Duration of untreated psychosis and acute remission of negative symptoms in a South American first-episode psychosis cohort. Early intervention in psychiatry, 11(1), 77-82. https://doi.org/10.1111/eip.12266

Gómez-de-Regil, L., Kwapil, T.R., Rosado-Franco, A., Barrantes-Vidal, N, 2010. Predictors of short-term course in Mexican first-episode psychosis patients. Salud Mental, 33(6),507-515. ISSN: 01853325. Available: https://www.redalyc.org/articulo.oa?id=58219792005

Kahn, R. S., Fleischhacker, W. W., Boter, H., Davidson, M., Vergouwe, Y., Keet, I. P., Gheorghe, M. D., Rybakowski, J. K., Galderisi, S., Libiger, J., Hummer, M., Dollfus, S., López-Ibor, J. J., Hranov, L. G., Gaebel, W., Peuskens, J., Lindefors, N., Riecher-Rössler, A., Grobbee, D. E., \& EUFEST study group., 2008. Effectiveness of antipsychotic drugs in first-episode schizophrenia and 
medRxiv preprint doi: https://doi.org/10.1101/2021.11.22.21266701; this version posted November 24, 2021. The copyright holder for this

schizophreniform disorder: an open randomised clinical trial. Lancet (London, England), 371(9618), 1085-1097. https://doi.org/10.1016/S0140-6736(08)60486-9

Kane, J. M., Schooler, N. R., Marcy, P., Correll, C. U., Brunette, M. F., Mueser, K. T., Rosenheck, R. A., Addington, J., Estroff, S. E., Robinson, J., Penn, D. L., \& Robinson, D. G., 2015. The RAISE early treatment program for first-episode psychosis: background, rationale, and study design. The Journal of clinical psychiatry, 76(3), 240-246. https://doiorg.eresources.mssm.edu/10.4088/JCP.14m09289

Kreyenbuhl J, Buchanan RW, Dickerson FB, Dixon LB; Schizophrenia Patient Outcomes Research Team (PORT), 2010 The Schizophrenia Patient Outcomes Research Team (PORT): updated treatment recommendations 2009. Schizophr Bull. 2010 Jan;36(1):94-103. doi: 10.1093/schbul/sbp130. Epub 2009 Dec 2. PMID: 19955388; PMCID: PMC2800150.

Lieberman, J. A., Alvir, J. M., Koreen, A., Geisler, S., Chakos, M., Sheitman, B., \& Woerner, M., 1996. Psychobiologic correlates of treatment response in schizophrenia. Neuropsychopharmacology: official publication of the American College of Neuropsychopharmacology, 14(3 Suppl), 13S21S. https://doi-org.eresources.mssm.edu/10.1016/0893-133X(95)00200-W

Malla, A., Norman, R., Schmitz, N., Manchanda, R., Béchard-Evans, L., Takhar, J., \& Haricharan, R., 2006. Predictors of rate and time to remission in first-episode psychosis: a two-year outcome study. Psychological medicine, 36(5), 649-658. https://doi.org/10.1017/S0033291706007379

Markkula, N., Alvarado, R., \& Minoletti, A., 2011. Adherence to guidelines and treatment compliance in the Chilean national program for first-episode schizophrenia. Psychiatric services (Washington, D.C.), 62(12), 1463-1469. https://doi.org/10.1176/appi.ps.001042011

McEvoy, J. P., Lieberman, J. A., Perkins, D. O., Hamer, R. M., Gu, H., Lazarus, A., Sweitzer, D., Olexy, C., Weiden, P., \& Strakowski, S. D., 2007. Efficacy and tolerability of olanzapine, quetiapine, and risperidone in the treatment of early psychosis: a randomized, double-blind 52-week comparison. The American journal of psychiatry, 164(7), 1050-1060. https://doi.org/10.1176/ajp.2007.164.7.1050 
medRxiv preprint doi: https://doi.org/10.1101/2021.11.22.21266701; this version posted November 24, 2021. The copyright holder for this

Mena C, Gonzalez-valderrama A, Iruretagoyena B, Undurraga J, Crossley NA., 2018. Early treatment resistance in a Latin-American cohort of patients with schizophrenia. Schizophr Res; Available from: https://doi.org/10.1016/j.schres.2018.02.056

Moreno-Küstner B, Martín C, Pastor L., 2018. Prevalence of psychotic disorders and its association with methodological issues. A systematic review and meta-analyses. PLoS One. 2018 Apr 12;13(4):e0195687. doi: 10.1371/journal.pone.0195687. PMID: 29649252; PMCID:

\section{PMC5896987.}

Nossel, I., Wall, M. M., Scodes, J., Marino, L. A., Zilkha, S., Bello, I., Malinovsky, I., Lee, R., Radigan, M., Smith, T. E., Sederer, L., Gu, G., \& Dixon, L., 2018. Results of a Coordinated Specialty Care Program for Early Psychosis and Predictors of Outcomes. Psychiatric services (Washington, D.C.), 69(8), 863-870. https://doi.org/10.1176/appi.ps.201700436

Olfson M, Gerhard T, Huang C, Crystal S, Stroup TS., 2015. Premature Mortality Among Adults with Schizophrenia in the United States. JAMA Psychiatry. 2015 Oct 28:1-10. doi: 10.1001/jamapsychiatry.2015.1737. PMID: 26509694

Perkins, D., Lieberman, J., Gu, H., Tohen, M., McEvoy, J., Green, A., Zipursky, R., Strakowski, S., Sharma, T., Kahn, R., Gur, R., Tollefson, G., \& HGDH Research Group., 2004. Predictors of antipsychotic treatment response in patients with first-episode schizophrenia, schizoaffective and schizophreniform disorders. The British journal of psychiatry: the journal of mental science, 185, 18-24. https://doi.org/10.1192/bjp.185.1.18

Rabinowitz, J., Harvey, P. D., Eerdekens, M., \& Davidson, M., 2006. Premorbid functioning and treatment response in recent-onset schizophrenia. The British journal of psychiatry: the journal of mental science, 189, 31-35. https://doi.org/10.1192/bjp.bp.105.013276

Robinson, D., Woerner, M. G., Alvir, J. M., Bilder, R., Goldman, R., Geisler, S., Koreen, A., Sheitman, B., Chakos, M., Mayerhoff, D., \& Lieberman, J. A., 1999. Predictors of relapse following response from a first episode of schizophrenia or schizoaffective disorder. Archives of general psychiatry, 56(3), 241-247. https://doi-org.eresources.mssm.edu/10.1001/archpsyc.56.3.241 
medRxiv preprint doi: https://doi.org/10.1101/2021.11.22.21266701; this version posted November 24, 2021. The copyright holder for this

Robinson, D. G., Woerner, M. G., McMeniman, M., Mendelowitz, A., \& Bilder, R. M., 2004.

Symptomatic and functional recovery from a first episode of schizophrenia or schizoaffective disorder. The American journal of psychiatry, 161(3), 473-479. https://doiorg.eresources.mssm.edu/10.1176/appi.ajp.161.3.473

Robinson, D. G., Gallego, J. A., John, M., Petrides, G., Hassoun, Y., Zhang, J. P., Lopez, L., Braga, R. J., Sevy, S. M., Addington, J., Kellner, C. H., Tohen, M., Naraine, M., Bennett, N., Greenberg, J., Lencz, T., Correll, C. U., Kane, J. M., \& Malhotra, A. K., 2015. A Randomized Comparison of Aripiprazole and Risperidone for the Acute Treatment of First-Episode Schizophrenia and Related Disorders: 3-Month Outcomes. Schizophrenia bulletin, 41(6), 1227-1236. https://doiorg.eresources.mssm.edu/10.1093/schbul/sbv125

Saha S, Chant D, Welham J, McGrath J., 2005. A systematic review of the prevalence of schizophrenia. PLoS Med. 2005 May;2(5):e141. doi: 10.1371/journal.pmed.0020141. Epub 2005 May 31. PMID: 15916472; PMCID: PMC1140952.

Santoro, M. L., Ota, V., de Jong, S., Noto, C., Spindola, L. M., Talarico, F., Gouvea, E., Lee, S. H., Moretti, P., Curtis, C., Patel, H., Newhouse, S., Carvalho, C. M., Gadelha, A., Cordeiro, Q., Bressan, R. A., Belangero, S. I., \& Breen, G., 2018. Polygenic risk score analyses of symptoms and treatment response in an antipsychotic-naive first episode of psychosis cohort. Translational psychiatry, 8(1), 174. https://doi.org/10.1038/s41398-018-0230-7

Schooler, N., Rabinowitz, J., Davidson, M., Emsley, R., Harvey, P. D., Kopala, L., McGorry, P. D., Van Hove, I., Eerdekens, M., Swyzen, W., De Smedt, G., \& Early Psychosis Global Working Group., 2005. Risperidone and haloperidol in first-episode psychosis: a long-term randomized trial. The American journal of psychiatry, 162(5), 947-953. https://doi.org/10.1176/appi.ajp.162.5.947

Trzesniak, C., Schaufelberger, M. S., Duran, F. L., Santos, L. C., Rosa, P. G., McGuire, P. K., Murray, R. M., Scazufca, M., Menezes, P. R., Hallak, J. E., Crippa, J. A., \& Busatto, G. F., 2012. Longitudinal follow-up of cavum septum pellucidum and adhesio interthalamica alterations in 
medRxiv preprint doi: https://doi.org/10.1101/2021.11.22.21266701; this version posted November 24, 2021. The copyright holder for this preprint (which was not certified by peer review) is the author/funder, who has granted medRxiv a license to display the preprint in perpetuity. All rights reserved. No reuse allowed without permission.

first-episode psychosis: a population-based MRI study. Psychological medicine, 42(12), 25232534. https://doi.org/10.1017/S0033291712000839

Valencia, M., Juarez, F., \& Ortega, H., 2012. Integrated treatment to achieve functional recovery for firstepisode psychosis. Schizophrenia research and treatment, 2012, 962371. https://doi.org/10.1155/2012/962371

Valencia, M., Juarez, F., Delgado, M., \& Díaz, A., 2017. Early intervention to improve clinical and functional outcome in patients with first episode- psychosis. https://www.iconceptpress.com/book/mental-disorder/11000123/1305000979.pdf. Accessed october 15, 2021. 
medRxiv preprint doi: https://doi.org/10.1101/2021.11.22.21266701; this version posted November 24, 2021. The copyright holder for this preprint (which was not certified by peer review) is the author/funder, who has granted medRxiv a license to display the preprint in perpetuity. All rights reserved. No reuse allowed without permission.

Figure 1. Flow diagram of patients entered into the study

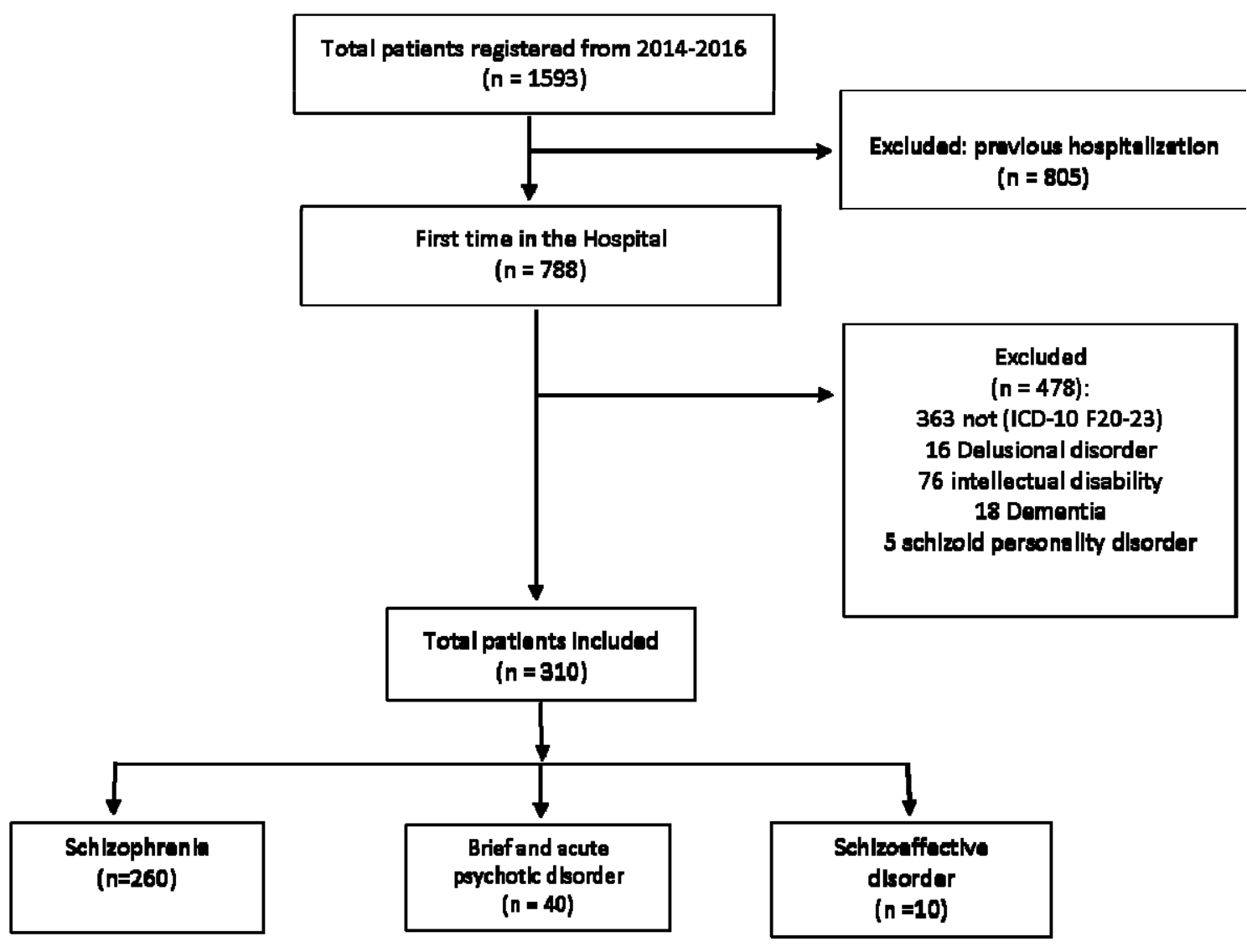


medRxiv preprint doi: https://doi.org/10.1101/2021.11.22.21266701; this version posted November 24, 2021. The copyright holder for this preprint (which was not certified by peer review) is the author/funder, who has granted medRxiv a license to display the preprint in perpetuity.

Table 1. Baseline Characteristics by Diagnostic Groups

\begin{tabular}{|c|c|c|c|c|c|}
\hline & $\begin{array}{c}\text { Overall } \\
(n=310)\end{array}$ & $\begin{array}{l}\text { Schizophreni } \\
\text { a }(n=260)\end{array}$ & $\begin{array}{l}\text { Schizoaffectiv } \\
\text { e disorder } \\
(n=10)\end{array}$ & $\begin{array}{c}\text { Brief } \\
\text { Psychotic } \\
\text { Disorder } \\
(n=40)\end{array}$ & $\begin{array}{c}\mathrm{p}- \\
\text { value }\end{array}$ \\
\hline & $\mathrm{n}(\%)$ & $\mathrm{n}(\%)$ & $\mathrm{n}(\%)$ & $\mathrm{n}(\%)$ & \\
\hline Male, $\mathrm{n}(\%)$ & 228(73.5) & $194(74.6)$ & $8(80.0)$ & $26(65.0)$ & 0.39 \\
\hline Age in years, median (IQR) & $25(19-38)$ & $25(19-37)$ & $35.5(24-48)$ & $\begin{array}{c}25(19.5- \\
38)\end{array}$ & 0.34 \\
\hline Single, $n(\%)[n=302]$ & $242(80.1)$ & $207(71.8)$ & $7(77.8)$ & $28(77.5)$ & 0.36 \\
\hline Years of Education, median (IQR) & $11(7-11)$ & $11(7-11)$ & $9(7-11)$ & $11(7-13)$ & 0.76 \\
\hline $\begin{array}{l}\text { Duration of untreated psychosis in days, } \\
\text { median (IQR) } \\
\text { Middle/high vs. Low SES, n(\%) }\end{array}$ & $\begin{array}{l}120(25.5- \\
720) \\
180(58.4)\end{array}$ & $180(60-720)$ & $180(90-300)$ & $\begin{array}{l}14(7-15) \\
19(48.7)\end{array}$ & $\begin{array}{c}<0.00 \\
1 \\
0.34\end{array}$ \\
\hline Urban vs. rural residence, $\mathrm{n}(\%)$ & $289(93.2)$ & $243(93.5)$ & $8(80)$ & $38(95)$ & \\
\hline Living situation, $\mathrm{n}(\%)$ & & & & & 0.66 \\
\hline Alone & $12(3.9)$ & $10(3.9)$ & $0(0)$ & $2(5)$ & \\
\hline With family & $280(90.3)$ & $236(90.8)$ & $10(100)$ & $31(85)$ & \\
\hline Institutionalized & $10(3.2)$ & $7(2.7)$ & $0(0)$ & $3(7.5)$ & \\
\hline Homeless & $3(1.0)$ & $3(1.2)$ & $0(0)$ & $0(0)$ & \\
\hline Hospitalized at presentation [309], n(\%) & $181(58.6)$ & $155(59.6)$ & $8(80)$ & $18(45)$ & 0.11 \\
\hline Hallucinations, $\mathrm{n}(\%)$ & $287(92.6)$ & $240(92.3)$ & $9(90.0)$ & $38(95.0)$ & 0.79 \\
\hline Delusions, $\mathrm{n}(\%)$ & $301(97.1)$ & $251(96.5)$ & $10(100)$ & $40(100)$ & 0.41 \\
\hline First-order symptoms, n(\%) [309] & $197(63.8)$ & $174(67.2)$ & $6(60)$ & $17(42.5)$ & 0.01 \\
\hline Disorganized thinking, $n(\%)$ [309] & $193(62.5)$ & $164(63.1)$ & $7(70)$ & $22(56.4)$ & 0.64 \\
\hline Disorganized behavior, $n(\%)$ [309] & $184(59.6)$ & $154(59.5)$ & $6(60)$ & $24(60)$ & 0.99 \\
\hline Catatonic symptoms, n(\%) & $16(5.2)$ & $14(5.4)$ & $1(10)$ & $1(2.5)$ & 0.58 \\
\hline \multicolumn{6}{|l|}{ Negative Symptons } \\
\hline Blunted or flat affect, $n(\%)$ & $192(61.9)$ & $173(66.5)$ & $5(50)$ & $14(35)$ & $\begin{array}{c}<0.00 \\
1\end{array}$ \\
\hline Alogia, $n(\%)$ & $81(26.1)$ & $75(28.9)$ & $2(20)$ & $4(10)$ & 0.037 \\
\hline Abulia, $n(\%)$ & $111(35.8)$ & $101(38.8)$ & $4(40)$ & $6(15)$ & 0.013 \\
\hline Aggressive behavior, $\mathrm{n}(\%)$ & $186(60)$ & $157(60.4)$ & $8(80)$ & $21(52.5)$ & 0.27 \\
\hline Insomnia, n(\%) & $206(66.5)$ & $172(66.2)$ & $7(70)$ & $27(67.5)$ & 0.96 \\
\hline \multicolumn{6}{|l|}{ Substance use disorder } \\
\hline Alcohol use disorder, $\mathrm{n}(\%)[308]$ & $20(6.5)$ & $15(5.8)$ & $2(20)$ & $3(7.5)$ & 0.20 \\
\hline Cannabis use disorder, $\mathrm{n}(\%)$ [308] & $127(41.2)$ & $113(43.8)$ & $4(40)$ & $10(25)$ & 0.08 \\
\hline Cocaine use disorder, n(\%) [307] & $81(26.4)$ & $71(27.6)$ & $2(20)$ & $8(20)$ & 0.53 \\
\hline Hallucinogen use disorder, n(\%) [308] & $63(20.5)$ & $56(21 x .7)$ & $0(0)$ & $7(17.5)$ & 0.22 \\
\hline Inhalants, n(\%) [306] & $20(6.5)$ & $19(7.4)$ & $0(0)$ & $1(2.6)$ & 0.37 \\
\hline
\end{tabular}

SES: Socioeconomic status 
medRxiv preprint doi: https://doi.org/10.1101/2021.11.22.21266701; this version posted November 24, 2021. The copyright holder for this preprint (which was not certified by peer review) is the author/funder, who has granted medRxiv a license to display the preprint in perpetuity. All rights reserved. No reuse allowed without permission.

Table 2. Treatment Characteristics of the Overall Sample

\begin{tabular}{llll}
\hline Antipsychotic & $\mathrm{N}(\%)$ & Median dose(IQR) & Mean dose (SD) \\
\hline Olanzapine & $186(60.2)$ & $10(10-20)$ & $12.6(5.7)$ \\
Risperidone & $143(46.3)$ & $3(2-4)$ & $3.0(1.6)$ \\
Haloperidol & $42(13.6)$ & $5(5-10)$ & $6.7(4.9)$ \\
Risperidone (LAI) & $35(11.4)$ & $37.5(25-50)$ & $37.1(13.7)$ \\
Pipotiazine Palmitate (LAI) & $22(7.1)$ & $25(25-25)$ & $26.1(5.3)$ \\
Clozapine & $21(6.8)$ & $200(100-300)$ & $215.5(135.0)$ \\
Quetiapine & $16(5.2)$ & $100(25-150)$ & $128.1(146.9)$ \\
Paliperidone Palmitate (LAI) & $4(1.3)$ & $112.5(75-150)$ & $112.5(443.3)$ \\
Aripiprazole & $3(0.97)$ & $30(15-30)$ & $25.0(8.7)$ \\
Amisulpride & $2(0.6)$ & $300(200-400)$ & $300(141.4)$ \\
Paliperidone & $1(0.3)$ & $6(6-6)$ & $6(\mathrm{NA})$ \\
Asenapine & $1(0.3)$ & $10(10-10)$ & $10(\mathrm{NA})$ \\
APP & $72(23.3)$ & $\mathrm{NA}$ & $\mathrm{NA}$ \\
Antidepressants & $73(23.9)$ & $\mathrm{NA}$ & $\mathrm{NA}$ \\
Mood Stabilizers & $79(25.6)$ & $\mathrm{NA}$ & $\mathrm{NA}$ \\
Benzodiazepines & $115(37.2)$ & $\mathrm{NA}$ & $\mathrm{NA}$ \\
Antiparkinsonian medications & $52(16.8)$ & $\mathrm{NA}$ & $\mathrm{NA}$ \\
\hline
\end{tabular}

LAl: Long Acting Injectable; APP: Antipsychotic Polypharmacy 